\title{
Pulmonary Hypoplasia
}

National Cancer Institute

\section{Source}

National Cancer Institute. Pulmonary Hypoplasia. NCI Thesaurus. Code C99035.

A cong enital abnormality in which the lung parenchyma is not fully developed. It may be associated with other congenital abnormalities. 